\title{
HUBUNGAN SENSE OF HUMOR, KECERDASAN EMOSIONAL DAN MOTIVASI BERPRESTASI TERHADAP HASIL BELAJAR MATEMATIKA SISWA KELAS X SMK TELADAN KOTA BATAM
}

\author{
Elsa Surya, Asmaul Husna* \\ Program Studi Pendidikan Matematika, Fakultas Keguruan dan Ilmu Pendidikan \\ Universitas Riau Kepulauan, Batam, Kepulauan Riau-Indonesia \\ e-mail: *asmaul_uul25@yahoo.com
}

\begin{abstract}
Abstrak. Penelitian ini bertujuan untuk mengetahui hubungan antara sense of humor, kecerdasan emosional dan motivasi berprestasi baik secara parsial maupun simultan terhadap hasil belajar matematika siswa Kelas X SMK Teladan Kota Batam Tahun Pelajaran 2016/2017. Penelitian ini merupakan penelitian korelasional. Populasi dalam penelitian ini adalah siswa kelas X SMK Teladan Kota Batam Tahun Pelajaran 2016/2017 sejumlah 314 siswa dengan jumlah sampel 106 siswa dengan menggunakan teknik simple random sampling. Penelitian ini menggunakan intrumen angket dengan teknik analisis instrumen validitas dan reliabilitas. Pengujian hipotesis dengan analisis korelasi sederhana dan analisis korelasi ganda, yang sebelumnya dilakukan uji prasyarat analisis meliputi uji normalitas dan liniearitas. Hasil penelitian menunjukkan bahwa: (1) Terdapat hubungan yang positif dan signifikan antara sense of humor terhadap hasil belajar matematika siswa yang ditunjukkan dengan koefisien korelasi parsial 0,292 dengan $t_{\text {hitung }}=3,117>t_{\text {tabel }}=1,983$. (2) Terdapat hubungan yang positif dan signifikan antara kecerdasan emosional terhadap hasil belajar matematika siswa yang ditunjukkan dengan koefisien korelasi parsial 0,328 dengan $t_{\text {hitung }}=3,535>t_{\text {tabel }}=1,983$ (3) Terdapat hubungan yang positif dan signifikan antara motivasi berprestasi terhadap hasil belajar matematika siswa yang ditunjukkan dengan koefisien korelasi parsial 0,909 dengan $t_{\text {hitung }}=22,215>t_{\text {tabel }} 1,983$ (4) Terdapat kontribusi positif dan signifikan antara sense of humor, kecerdasan emosional dan motivasi berprestasi secara bersama-sama terhadap hasil belajar matematika siswa yang ditunjukkan dengan koefisien korelasi ganda sebesar 0,910 dengan $\mathrm{F}_{\text {hitung }} 162,983>\mathrm{F}_{\text {tabel }} 2,693$.
\end{abstract}

Kata Kunci : sense of humor, kecerdasan emosional, motivasi berprestasi, hasil belajar matematika

Abstract.This research aims to determine the relationship between the sense of humor, emotional intelligence and achievement motivation either partially or simultaneously to the results of learning mathematics students Class X SMK Teladan Batam City Lesson 2016/2017. This research is a correlational research. The population in this study were the students of class X SMK Teladan Batam City Lesson Year 2016/2017 a number of 314 students with a sample of 106 students use simple random sampling This research used quessioner analysis, instrument analysis technic validity and reliability. Hypothesis testing with simple correlation analysis and multiple correlation analysis, previously performed test requirements analysis include test of normality and linearity. The results showed that: (1) There is a positive and significant relationship between the sense of humor on the mathematics learning outcomes of students which is shown by partial correlation coefficient of 0.292 $t_{\text {count }}=3,117>t_{\text {table }}=1,983$. (2) There is a positive and significant correlation between emotional intelligence to student's mathematics learning result shown by partial correlation coefficient 0,328 with $t_{\text {count }}=3,535>t_{\text {table }}=1,983$ (3) There is positive and significant correlation between achievement motivation toward student learning achievement result show by partial correlation coefficient 0,909 with $t_{\text {count }}=22,215>t_{\text {table }} 1,983$ (4) There is a positive and significant contribution between the sense of humor, emotional intelligence and achievement motivation jointly to the student's mathematics learning outcomes shown by the double correlation coefficient of 0.910 with $F_{\text {count }} 162,983>F_{\text {table }}$ 2,693 .

Key Words: sense of humor, emotional intelligence, achievement motivation, student learning outcomes mathematics 


\section{Pendahuluan}

Pendidikan tentunya telah menjadi hal yang sangat wajib bagi kehidupan manusia. Berbagai hal yang diharapkan untuk mewujudkan cita-cita pastilah melalui proses yang disebut pendidikan. Pendidikan adalah usaha yang dilakukan secara sadar dan sengaja untuk mengubah tingkah laku manusia baik secara individu maupun kelompok untuk mendewasakan manusia melalui upaya pengajaran (sugihartono, 2007).

Salah satu tujuan yang ingin dicapai dalam proses pendidikan adalah tercapainya prestasi belajar siswa yang maksimal. Sebagaimana tercantum dalam UU No. 20 Tahun 2003 tentang Sistem Pendidikan Nasional pasal 3 bahwa Pendidikan Nasional berfungsi mengembangkan kemampuan dan membentuk watak serta peradaban bangsa yang bermartabat dalam rangka mencerdaskan kehidupan bangsa, bertujuan untuk berkembangnya potensi peserta didik agar menjadi manusia yang beriman dan bertakwa kepada Tuhan Yang Maha Esa, berakhlak mulia, sehat, berilmu, cakap, kreatif, mandiri, dan menjadi warga negara yang demokratis serta bertanggung jawab.

Prestasi belajar yang merupakan salah satu tujuan dari proses belajar itu sendiri merupakan hasil belajar yang diperoleh siswa, sebagai hasil dari proses belajar mengajar yang diberikan oleh guru (Kertamuda, 2008). Observasi awal yang dilakukan oleh peneliti maka didapatkan informasi bahwa siswa SMK Teladan Kota Batam persentase siswa yang tidak tuntas lebih besar dari pada yang tuntas, hal ini dibuktikan dengan nilai UAS Matematika siswa pada Tabel 1.

Tabel 1. Data Nilai UAS Matematika Siswa SMK Teladan Batam

\begin{tabular}{lccccc}
\hline \multicolumn{1}{c}{ Kelas } & $\begin{array}{c}\text { Nilai } \\
\text { Rata-Rata }\end{array}$ & Tuntas & \% & $\begin{array}{c}\text { Tidak } \\
\text { Tuntas }\end{array}$ & \% \\
\hline X. T.Elektronika Industri & 69,41 & 11 & 55 & 9 & 45 \\
X.T.Kendaraan Ringan & 71,89 & 12 & 75 & 4 & 25 \\
$\begin{array}{l}\text { X.T.Industri Tenaga Listrik } \\
\text { X.T.Komputer dan }\end{array}$ & 70,6 & 29 & 57,58 & 14 & 42,42 \\
$\quad \begin{array}{l}\text { Jaringan } \\
\text { X.T.Konstruksi Kapal Baja }\end{array}$ & 73,20 & 26 & 87,67 & 4 & 13,33 \\
\hline Sunn & 67,54 & 23 & 62,86 & 13 & 37,14 \\
\hline
\end{tabular}

Sumber: Guru mata pelajaran Matematika SMK Teladan Batam

Berdasarkan Tabel 1 di atas terlihat bahwa Nilai rata-rata Matematika siswa kelas $\mathrm{X}$ SMK Teladan Kota Batam dua kelas masih dibawah KKM yang dibandingkan dengan KKM 70. Adapun yang menjadi penyebab hal tersebut pada hakikatnya terletak pada kesadaran siswa dalam belajar untuk lebih baik masih rendah, Siswa belajar dalam keadaan yang tidak kondusif sehingga akan mempengaruhi proses pembelajaran. Selain keadaan kondisi dan situasi pembelajaran, faktor guru dan motivasi berprestasi siswa SMK Teladan juga dapat menjadi masalah dalam pembelajaran, Hal ini didasari oleh (Narwoto, 2013) yang menyebutkan bahwa faktor-faktor yang mempunyai pengaruh kuat terhadap hasil belajar antara lain: kinerja mengajar guru, pemanfaatan fasilitas belajar dan motivasi berprestasi siswa.

Fakta lain didapat oleh peneliti melalui wawancara dengan beberapa orang siswa SMK Teladan Kota Batam bahwa hasil belajar matematika yang belum memuaskan dikarenakan kurangnya Sense Of Humor (selera humor) yang diterapkan oleh guru mata pelajaran dalam 
pembelajaran matematika. Menurut (Sungkar \& Partini, 2015) Sense of humor merupakan suatu potensi yang ada di dalam individu yang reaksinya dimunculkan dengan emosi riang dan gembira disertai senyum dan tawa yang sebelumnya berlangsung adanya proses berfikir. Menurut (Puspitacandri, 2013) Sense of humor adalah kemampuan yang dimiliki individu untuk tertawa dan membuat orang lain tertawa, termasuk menertawakan diri sendiri sehingga mampu memunculkan sikap positif pada diri maupun lingkungan. Akibat dari kurangnya selera humor guru maka iklim pembelajaran di kelas menjadi kurang kondusif dan membosankan, serta berdampak pada pembelajaran yang kurang efektif misalnya guru yang begitu serius atau biasa dikenal guru killer dapat mempengaruhi siswa dalam belajar.

Tidak bisa kita pungkiri selera humor yang dimiliki oleh seorang dapat membuat suasana belajar siswa menjadi lebih kondusif dan menyenangkan. Dengan catatan humor yang dilakukan oleh guru tidak berlebihan dan tetap dengan konsep pembelajaran yang baik. Dengan humor yang diterapkan kepada siswa diharapkan siswa menjadi tertarik dan memusatkan perhatiannya untuk mengikuti pembelajaran. Hal ini juga dinilai baik agar menciptakan suasana pembelajaran yang menyenangkan dan menarik (Karmila \& Husna, 2017). Penerapan Sense Of Humor guru di kelas terbukti memiliki kontribusi terhadap hasil belajar sesuai dengan penelitian yang dilakukan oleh (Kristiandi, 2009) menunjukkan bahwa adanya hubungan yang positif antara presepsi siswa terhadap Sense Of Humor guru dengan motivasi belajar siswa terhadap hasil belajar siswa.

Adapun faktor lain yang dapat mempengaruhi hasil belajar belajar adalah kecerdasan emosional dan motivasi berprestasi. Melalui wawancara dengan guru Mata Pelajaran Matematika didapat informasi bahwa kurangnya motivasi berprestasi siswa dalam mengikuti pembelajaran di kelas dapat dilihat dari kepedulian siswa terhadap pembelajaran di kelas seperti kurangnya respon dan siswa sulit berkonsentrasi dalam pembelajaran matematika (Yaniwati \& Husna, 2017). Selain itu didapat juga informasi melalui Guru Bimbingan Konseling bahwa kurangnya motivasi belajar siswa dapat dilihat melalui banyaknya siswa yang cabut ketika jam belajar serta kurangnya keinginan siswa untuk lebih peduli terhadap apa yang sedang diterangkan oleh guru. Pada dasarnya motivasi berprestasi tidaklah jauh berbeda dengan motivasi belajar siswa. Dapat disebutkan juga bahwasanya motivasi berprestasi merupakan turunan yang spesifik dari motivasi belajar siswa. Motivasi berprestasi akan mendorong siswa untuk berkompetisi secara sehat meningkatkan hasil belajar.Menurut (Erlanggono, Kurniawan, \& Dkk, 2013). Motivasi berprestasi dapat diartikan sebagai dorongan dari dalam individu untuk mencapai hasil terbaik dengan upaya sebaik mungkin. Boocock (Firmansyah, 2009) menyebutkan Motivasi berprestasi merupakan kecenderungan seseorang untuk mereaksi terhadap situasi untuk mencapai suatu prestasi yang ditampilkan dalam bentuk tingkah laku.Menurut Clelland (Tejo, 2010). Motivasi berprestasi ialah keinginan untuk berbuat sebaik mungkin tanpa banyak dipengaruhi oleh prestise dan pengaruh sosial, melainkan demi kepuasan pribadinya, (Dewi, 2013). Motivasi berprestasi adalah suatu keinginan untuk berhasil, meraih sukses dan menjadi yang terbaik dengan bekerja sebaik mungkin dengan usaha yang sungguh-sungguh untuk mencapai sebuah standar keunggulan dan mencurahkan usaha untuk mengungguli. 
Sedangkan untuk faktor Kecerdasan Emosional menurut guru mata pelajaran matematika siswa juga banyak siswa yang kurang mampu mengelola emosinya dalam kegiatan pemebelajaran. Howard dalam (Nggermanto, 2015) kecerdasan emosional terdiri atas dua kecakapan yaitu: intra personal intelligence dan interpersonal intelligence. Sedangkan menurut (Nggermanto, 2015) kecerdasan emosional mencakup kemampuankemampuan yang berbeda, tetapi saling melengkapi, dengan kecerdasan akademik (academic intelligence) yaitu kemampuan-kemampuan kognitif murni yang diukur dengan IQ. Menurut (Angelia \& Madiono, 2013) kecerdasan emosional merupakan kemampuan seseorang untuk bisa mengenal dirinya sendiri dengan lebih baik dan mengenal orang lain sehingga akan mampu menjalin sebuah hubungan yang harmonis dengan orang lain. Ary dalam (Kuswandi, Mulyadi, \& Dkk, 2012) kecerdasan emosional adalah sebuah kemampuan untuk mendengarkan bisikan emosi dan menjadikannya sebagai sumber informasi maha penting untuk memahami diri sendiri dan orang lain untuk mencapai tujuan. Berdasarkan hasil observasi peneliti contoh nyata dari siswa yang emosinya yang kurang stabil dan mudah marah dalam pembelajaran sehingga akan membuat siswa tersebut keliru dalam menentukan dan memecahkan permasalahan yang ada pada pelajaran matematika, tidak hanya itu siswa yang tidak dapat mengelola emosinya juga memberikan dampak yang buruk terhadap kerja sama kelompak hal ini dapat di lihat ketika siswa dibentuk kerja sama kelompok, emosi yang kurang terjaga akan mambuat siswa tersebut sangat bersemangat tapi hanya dalam waktu singkat, sehingga kerja sama kelompok yang harusnya berjalan dengan baik akan berubah jadi kegagalan dalam mencapai target indikator pembelajaran matematika.

\section{Metode Penelitian}

Jenis penelitian yang digunakan dalam penelitian ini adalah penelitian kuantitatif. Metode penelitian menggunakan penelitian korelasional, dengan design yang digunakan dalam penelitian ini adalah sebagai berikut:

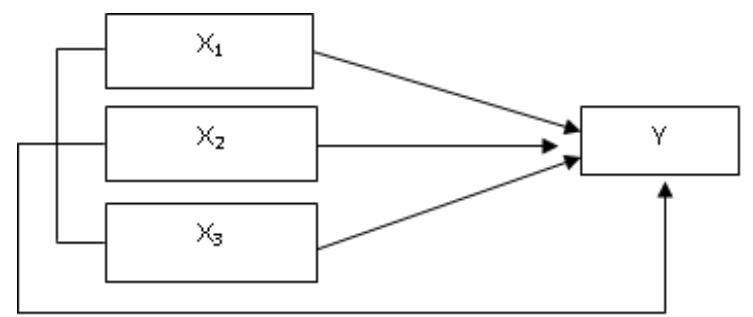

Gambar 1. Desain Penelitian

Populasi dalam penelitian ini adalah seluruh siswa kelas kelas X SMK Teladan Kota Batam tahun ajaran 2016/2017 sebanyak 314 siswa.. Pengambilan sampel pada penelitian ini adalah dengan teknik Simple Random Sampling. Menurut (sugiyono, 2012) Dikatakan simple (sederhana) karena pengambilan anggota sampel dari populasi dilakukan secara acak tanpa ada memperhatikan strata yang ada dalam populasi itu Menurut (Riduwan, 2011) pengambilan sampel dengan teknik simple random sampling yaitu sampel diambil dari populasi yang dilakukan dengan acak tanpa memperhatikan tingkatan dalam anggota populasi tersebut. Dengan menggunakan rumus Taro Yamane maka didapat jumlah sampel yaitu sebanyak 106 siswa. 
Variabel bebas dalam penelitian ini adalah Sense Of Humor $\left(\mathrm{X}_{1}\right)$, Kecerdasan Emosional $\left(\mathrm{X}_{2}\right)$ dan Motivasi Berprestasi $\left(\mathrm{X}_{3}\right)$. Variabel terikat dalam penelitian ini adalah Hasil Belajar Matematika siswa kelas X SMK Teladan Kota Batam Tahun Pelajaran 2016/2017. Teknik pengumpulan data yang digunakan dalam penelitian ini menggunakan angket. Angket digunakan untuk mengukur Sense Of Humor, Kecerdasan Emosional dan Motivasi Berprestasi terhadap Hasil Belajar Matematika siswa.

Dari hasil uji validitas instrumen hasil pengolahan data uji coba angket terdapat 23 soal valid untuk angket Sense Of Humor, 24 soal valid untuk angket kecerdasan emosional, 20 soal valid untuk angket motivasi berprestasi. Peneliti menggunakan validitas konstruk dengan rumus Pearson Product Moment. Sedangkan untuk menguji reliabilitas instrumen angket dalam penelitian ini, digunakan rumus Alpha Cronbach karena jenis data yang digunakan berbentuk ordinal. Hasil dari koefisien Alpha Cronbach dari masing-masing instrumen sense of humor menunjukkan angka 0,901, kecerdasan emosional menunjukkan angka 0,865 dan motivasi berprestasi menunjukkan angka 0,841 jadi karena angka yang didapat untuk uji reliabiltas ketiga instrument $>0,8$ sehingga semua instrumen memiliki reliabilitas dengan kategori sangat tinggi. Untuk uji prasyarat analisis dalam penelitian ini adalah normalitas menggunakan Kolmogorov Smirnov, dan uji liniearitas menggunakan Test For Linearity. Uji hipotesis 1, 2 dan 3 menggunakan Pearson Product Moment dan uji t satu pihak untuk menghitung besarnya signifikansi masing-masing variabel terhadap hasil belajar, dan uji hipotesis 4 menggunakan regresi linier berganda dengan 3 prediktor dan uji F.

\section{Hasil Penelitian Dan Pembahasan}

Setelah melakukan penelitian dengan menyebarkan angket kepada siswa kelas X SMK Teladan Kota Batam Tahun Pelajaran 2016/2017 sejumlah 106 sampel penelitian, maka diperoleh data hasil penelitian sebagai berikut:

Tabel 2. Deskriptif Statistik Variabel Penelitian

\begin{tabular}{lccccccc}
\hline \multicolumn{1}{c}{ Variabel } & Mean & Median & Modus & $\begin{array}{c}\text { Std. } \\
\text { Deviation }\end{array}$ & Min & Max \\
\hline Hasil Belajar Matematika(Y) & 68,22 & 68 & 64 & 8,102 & 53 & 84 \\
Sense Of Humor $\left(\mathbf{X}_{\mathbf{1}}\right)$ & 71,78 & 71 & 71 & 7,944 & 51 & 92 \\
Kecerdasan Emsional $\left(\mathbf{X}_{\mathbf{2}}\right)$ & 76,28 & 75,5 & 72 & 9,071 & 57 & 96 \\
Motivasi Berprestasi $\left(\mathbf{X}_{\mathbf{3}}\right)$ & 64 & 63 & 58 & 7,610 & 51 & 80 \\
\hline
\end{tabular}

Sebelum data dianalisis untuk menguji hipotesis, terlebih dahulu data harus memenuhi syarat normal dan linier. Data diperoleh dari hasil penyebaran angket kepada siswa sampel penelitian. Pada uji prasyarat ini, uji normalitas menggunakan Kolmogorov Smirnov, sedangkan uji liniearitas menggunakan Test For Linearity dengan bantuan SPSS For Windows version 20.0. Berdasarkan data yang diperoleh nilai signifikansi variabel Sense Of Humor adalah 0.200, variabel Kecerdasan Emosional adalah 0.121, variabel Motivasi Berprestasi adalah 0.057 dan variabel Hasil Belajar Matematika adalah 0.103, maka dapat disimpulkan 
(Sig) > 0.05 maka variabel Sense Of Humor, Kecerdasan Emosional dan Motivasi Berprestasi terhadap Hasil Belajar Matematika siswa dinyatakan berdistribusi normal. Hasil uji liniearitas menunjukkan bahwa nilai signifikansi antara variabel $\mathrm{X}_{1}$ terhadap $\mathrm{Y}$ adalah 0.923 , variabel $\mathrm{X}_{2}$ terhadap $\mathrm{Y}$ adalah 0.678 dan variabel $\mathrm{X}_{3}$ terhadap $\mathrm{Y}$ adalah 0.646 , maka dapat disimpulkan (Sig) > 0.05 sehingga dinyatakan variabel bebas dan variabel terikat memiliki hubungan linier.

Adapun hasil pengujian hipotesis dalam penelitian ini dapat dilihat dengan tabel nilai korelasi dan kontribusi variabel bebas terhadap variabel terikat berikut:

Tabel 3. Nilai Korelasi dan Kontribusi Variabel Bebas Terhadap Variabel Terikat

\begin{tabular}{lcccc}
\hline Variabel & Nilai Korelasi & Kontribusi & $\mathbf{t}_{\text {hitung }}$ & $\mathbf{F}_{\text {hitung }}$ \\
\hline $\mathbf{X}_{\mathbf{1}} \mathbf{Y}$ & 0,292 & $8,54 \%$ & 3,117 & - \\
$\mathbf{X}_{\mathbf{2}} \mathbf{Y}$ & 0,328 & $10,73 \%$ & 3,535 & - \\
$\mathbf{X}_{\mathbf{3}} \mathbf{Y}$ & 0,909 & $82,59 \%$ & 22,215 & - \\
$\mathbf{X}_{\mathbf{1}} \mathbf{X}_{\mathbf{2}} \mathbf{X}_{\mathbf{3}} \mathbf{Y}$ & 0,910 & $82,7 \%$ & - & 162,983 \\
\hline
\end{tabular}

Berdasarkan hasil penelitian menunjukkan bahwa terdapat hubungan yang positif dan signifikan antara Sense of Humor terhadap hasil belajar siswa. Hal ini ditunjukkan dengan koefisien korelasi $\left(\mathrm{r}_{\mathrm{x} 1 \mathrm{y}}=0,292>0\right)$. Dimana dari hasil perhitungan diperoleh $\mathrm{t}_{\text {hitung }}(3,117)>$ $\mathrm{t}_{\text {tabel }}(1,983)\left(\mathrm{n}=106\right.$, taraf signifikan 95\%). sedangkan harga koefisien determinasi $\left(\mathrm{R}^{2}\right)$ sebesar 0,0854 atau sebesar 8,54\% ini berarti bahwa sense of humor memberikan sumbangan terhadap hasil belajar matematika siswa sebesar $8,54 \%$, sisanya sebesar $91,46 \%$ dipengaruhi oleh variabel lain Hal ini diperkuat oleh penelitian sebelumnya yang dilakukan oleh Yuli (2016) yang mengemukakan bahwa Sense Of Humor memiliki hubungan yang positif dan signifikan terhadap prestasi belajar siswa.

Sense Of Humor yang memiliki hubungan positif dan signifikan terhadap Hasil Belajar Matematika berarti semakin tinggi Sense Of Humor, maka akan semakin tinggi pula Hasil Belajar Matematika dan sebaliknya semakin rendah Sense Of Humor siswa maka akan semakin rendah pula Hasil Belajar Matematika siswa tersebut. Dari hasil penelitian di atas maka disimpulkan bahwa Sense Of Humor memiliki hubungan positif dan signifikan terhadap Hasil Belajar Matematika siswa.

Berdasarkan hasil penelitian menunjukkan bahwa terdapat hubungan yang positif dan signifikan antara Kecerdasan Emosional terhadap Hasi Belajar Matematika siswa. Hal ini ditunjukkan dengan koefisien korelasi $\left(\mathrm{r}_{\mathrm{x} 2 \mathrm{y}}\right)$ sebesar 0,328. Dimana dalam hasil perhitungan diperoleh $t_{\text {hitung }}(3,535)>t_{\text {tabel }}(1,983)(n=106$, taraf signifikan 95\%). Sedangkan harga koefisien determinasi $\left(\mathrm{R}^{2}\right)$ sebesar 0,1073 atau sebesar $10,73 \%$ ini berarti bahwa kecerdasan emosional memberi sumbangan $10,73 \%$ terhadap hasil belajar matematika, sisanya 89,27 \% dipengaruhi oleh variabel lain. pernyataan ini diperkuat oleh penelitian sebelumnya oleh (Daud, 2012) yang mengemukakan bahwa Kecerdasan Emosional memiliki pengaruh yang positif dan signifikan terhadap Hasi Belajar Matematika siswa.

Kecerdasan Emosional yang memiliki hubungan positif dan signifikan terhadap Hasil Belajar Matematika berarti semakin tinggi pengetahuan siswa tentang Kecerdasan Emosional, maka akan semakin tinggi pula Hasil Belajar Matematika dan sebaliknya semakin rendah 
Kecerdasan Emosional siswa maka akan semakin rendah pula Hasil Belajar Matematika siswa tersebut. Dari hasil penelitian di atas maka disimpulkan bahwa Kecerdasan Emosional memiliki hubungan positif terhadap Hasil Belajar Matematikasiswa.

Berdasarkan hasil penelitian menunjukkan bahwa terdapat hubungan yang positif dan signifikan antara Motivasi Berprestasi terhadap Hasil Belajar Matematika siswa. Hal ini ditunjukkan dengan koefisien korelasi $\left(\mathrm{r}_{\mathrm{x} 3 \mathrm{y}}\right)$ sebesar 0,909. Dimana dalam hasil perhitungan diperoleh $t_{\text {hitung }}(22,216)>t_{\text {tabel }}(1,983)(n=106$, taraf signifikan 95\%). Sedangkan harga koefisien determinasi $\left(\mathrm{R}^{2}\right)$ sebesar 0,8259 atau sebesar $82,59 \%$ artinya motivasi berperestasi memberi sumbangan $82,59 \%$ terhadap hasil belajar, sisanya $17,41 \%$ dipengaruhi variabel lain . pernyataan ini diperkuat oleh penelitian sebelumnya oleh (Qalsum, 2015) yang mengemukakan bahwa Motivasi Berprestasi memiliki pengaruh yang positif dan signifikan terhadap Hasil Belajar Matematika siswa.

Motivasi Berprestasi yang memiliki hubungan yang positif dan signifikan terhadap Hasil Belajar Matematika berarti semakin tinggi Motivasi Berprestasi siswa, maka akan semakin tinggi pula Hasil Belajar Matematika dan sebaliknya semakin rendah Motivasi Berprestasi siswa maka akan semakin rendah pula Hasil Belajar Matematika siswa tersebut. Dari hasil penelitian di atas maka disimpulkan bahwa Motivasi Berprestasi memiliki hubungan positif dan signifikan terhadap Hasil Belajar Matematikasiswa.

Berdasarkan hasil penelitian menunjukkan bahwa terdapat hubungan antara Sense Of Humor, Kecerdasan Emosional dan Motivasi Berprestasi secara bersama-sama terhadap Hasil Belajar Matematikasiswa. Hal ini ditunjukkan dengan koefisien korelasi $\left(\mathrm{R}_{\mathrm{x} 1 \times 2 \times 3 \mathrm{y}}\right)$ sebesar 0,910. Dimana dalam hasil perhitungan diperoleh $F_{\text {hitung }}(162,983)>F_{\text {tabel }}(2,693)(n=106$, taraf signifikan 95\%). Sedangkan harga koefisien determinasi $\left(\mathrm{R}^{2}\right)$ sebesar 0,827 atau sebesar 82,7\% artinya Sense Of Humor, Kecerdasan Emosional dan Motivasi Berprestasi secara bersama-sama member sumbangan sebesar $82,7 \%$ terhadap hasil belajar dan sisanya $17,3 \%$ dipengaruhi oleh variabel lain.Pernyataan ini diperkuat oleh penelitian sebelumnya oleh (Sugiarto, 2016) yang mengemukakan bahwa terdapat pengaruh positif dan signifikan antara presepsi siswa tentang selera humor guru dan motivasi belajar terhadap prestasi belajar siswa.

\section{Kesimpulan Dan Saran}

Berdasarkan penelitian dan pembahasan yang telah dilakukan, diperoleh kesimpulan, yaitu:

1. Terdapat hubungan yang positif dan signifikan antara Sense Of Humor terhadap hasil belajar matematika siswa yang ditunjukkan dengan koefisien korelasi parsial 0,292 dan nilai koefisien determinasi Sense Of Humor terhadap hasil belajar matematika 8,54\% ini berarti bahwa sense of humor memberikan sumbangan terhadap hasil belajar matematika siswa sebesar $8,54 \%$, sisanya sebesar $91,46 \%$ dipengaruhi oleh variabel lain.

2. Terdapat hubungan yang positif dan signifikan antara kecerdasan emosional terhadap hasil belajar matematika siswa yang ditunjukkan dengan koefisien korelasi parsial 0,328 dan besarnya nilai koefisien determinasi kecerdasan emosional terhadap hasil belajar matematika adalah $10,73 \%$ ini berarti bahwa kecerdasan emosional memberikan 
sumbangan terhadap hasil belajar matematika siswa sebesar $10,73 \%$, sisanya sebesar $89,27 \%$ dipengaruhi oleh variabel lain.

3. Terdapat hubungan yang positif dan signifikan antara motivasi berprestasi terhadap hasil belajar matematika siswa yang ditunjukkan dengan koefisien korelasi parsial 0,909 dan besarnya nilai koefisien determinasi kecerdasan emosional terhadap hasil belajar matematika adalah $82,59 \%$ ini berarti bahwa motivasi berprestasi memberikan sumbangan terhadap hasil belajar matematika siswa sebesar $82,59 \%$, sisanya sebesar $17,41 \%$ dipengaruhi oleh variabel lain

4. Terdapat hubungan yang positif dan signifikan antara Sense Of Humor, kecerdasan emosional dan motivasi berprestasi secara bersama-sama terhadap hasil belajar matematika siswa yang ditunjukkan dengan koefisien korelasi ganda sebesar 0,910 dan besarnya nilai koefisien determinasi adalah $82,7 \%$, sisanya $17,3 \%$ dipengaruhi oleh faktor lain yang tidak terdapat dalam penelitian ini

Berdasarkan hasil penelitian dan kesimpulan yang telah diuraikan diatas maka dapat diberikan beberapa saran sebagai berikut:

1. Bagi Siswa

Siswa harus mempunyai motivasi berprestasi yang tinggi. Hal tersebut dapat dilakukan diantaranya dengan menumbuhkan rasa senang, tertarik dan penuh perhatian terhadap mata pelajaran matematika.

2. Bagi Guru

Guru diharapkan dapat melakukan meningkatkan hasil belajar matematika dengan memberikan dorongan kepada siswa untuk memberikan perasaan senang, tertarik dan penuh perhatian terhadap pelajaran matematika dengan cara pendekatan komunikasi yang variatif dan menyenangkan salah satunya dengan humor. Motivasi belajar bisa ditumbuhkan melalui peran guru yaitu guru yang mempunyai selera humor dan kemampuan humor untuk meredakan ketegangan.

3. Bagi sekolah

Sekolah diharapkan meningkatkan kemampuan guru dalam interaksi komunikasi di kelas dengan cara pendidikan dan latihan. Sehingga siswa tidak ada kecanggungan dalam berkomunikasi dengan guru, siswa akan lebih aktif dalam berkomunikasi di dalam pembelajaran.

\section{Daftar Pustaka}

Angelia, V., \& Madiono, E. (2013). Kontribusi Gaya Kepemimpinan Kepala Sekolah Dan MotivasiBerprestasi Guru Terhadap Mutu Pendidikan Di Gugus Rama 2 UptDisdikpora Kecamatan Kembang Kabupaten Jepara. JMP, 2(1).

Daud,F. (2012). Pengaruh Kecerdasan Emosional (EQ) dan Motivasi Belajar Terhadap Hasil Belajar Biologi siswa SMA Negeri 3 Kota Palopo. Pendidikan Dan Pembelajaran, 19(2).

Dewi, P. D. (2013). Kontribusi Gaya Kepemimpinan Kepala Sekolah dan Motivasi Berprestasi Guru Terhadap Mutu Pendidikan di Gugus Rama 2 UPT DISDIKPORA 
Kecamatan Kembang Kabupaten Jepara. JMP, 2(1).

Erlanggono, E., Kurniawan, E. S., \& Dkk. (2013). Peningkatan Motivasi Berprestasi IPA Fisika dengan memanfaatkan Computer Assisted Intruction (CAI) Pada Siswa SMP N 6 Purworwjo Tahun Pelajaran 2012/2013. Radiasi, 2(1).

Firmansyah, H. (2009). Hubungan Motivasi Berprestasi Siswa dengan Hasil Belajar Pendidikan Jasmani. Pendidikan Jasmani Indonesia, 6(1).

Karmila, E., \& Husna, A. (2017). Peningkatan Kreativitas Siswa Dalam Membuat Karya Kerajinan Tangan Melalui Pendekatan Kontruktivisme Di Kelas IV Sekolah Dasar Negeri 25 Air Dingin Kecamatan Lembah Gumanti, 6(3), 453-463.

Kertamuda, F. (2008). Pengaruh Motivasi Belajar terhadap Prestasi Belajar. Psikologika: Jurnal Pemikiran Dan Penelitian Psikologi, 21(1), 25-38.

Kristiandi. (2009). Hubungan Persepsi Siswa Terhadap Sense of Humor Guru dengan Motivasi Belajar Di Kelas 7 Internasional Sekolah Menengah Pertama Negeri 1 Medan.

Kuswandi,M., Mulyadi, D., \& Dkk. (2012). Pengaruh Kecerdasan Emosional Terhadap Kinerja Karyawan Pada Kantor Kementrian Agama Kabupaten Karawang. Manajemen, 10(1).

Narwoto. (2013). Faktor-Faktor Yang Berpengaruh Terhadap Prestasi Belajar Teori Kejuruan siswa SMK. Pendidikan Vokasi, 2(2).

Nggermanto, A. (2015). Kecerdasan Quantum.

Puspitacandri, A. (2013). Pengaruh Kreativitas Verbal Terhadap Sense Of Humor Siswa Akselerasi. Jurnal Psikologi Tabularasa, 8(2), 681-690.

Qalsum, U. dkk. (2015). Hubungan antara konsep diri dan Motivasi Berprestasi dengan Hasil Belajar Fisika Peserta Didik SMK di Kota Makasar. Sains Dan Pendidikan Fisika, 11(2).

Riduwan. (2011). Dasar-Dasar Statistika. Bandung : Alfabeta

Sugiarto, Y. (2016). Pengaruh Persepsi Siswa Tentang Selera Humor Guru Dan Motivasi Belajar Terhadap Prestasi Belajar Mata Pelajaran Ekonomi siswa kelas XI IPS SMA Negeri Yogyakarta. UNY.

Sugihartono. (2007). Psikologi Pendidikan.Yogyakarta : UNY Press

Sugiyono. (2012). Statistik untuk Penelitian. Bandung : Alfabeta

Sungkar,Y., \& Partini. (2015). Sense Of Humor Sebagai Langkah Meningkatkan Kepercayaan Diri Guru PPL Dalam Proses Belajar Mengajar. INDIEGENEOUS, 13(1), 92-101.

Tejo, N. (2010). Pembelajaran Motivasi Berprestasi Dalam Mata Kuliah Kewirausahaan Dengan Game Tournament. Ekonomi Dan Pendidikan, 7(1). 
Yaniwati, A., \& Husna, A. (2017). Efektivitas Pembelajaran Think Pair Share (TPS) Dan The Power Of Two (TPT) Terhadap Hasil Belajar Matematika Siswa Kelas VIII Smp Negeri 10 Batam. PYTHAGORAS, 6(2), 126-132. 